\title{
RESILIENCE OF DIKES AFTER INITIAL DAMAGE BY WAVE ATTACK
}

\author{
M. Klein Breteler ${ }^{1}$, M. Bottema ${ }^{2}$, G.A.M. Kruse ${ }^{1}$, G.C. Mourik ${ }^{1}$ and A. Capel ${ }^{1}$
}

\begin{abstract}
The resilience of a dike is quantified in this research as the residual strength, which is the time between initial damage to a dike and dike breach. Unique experiments have been carried out in the Delta Flume of Deltares with a $8.5 \mathrm{~m}$ high dike with a clay liner and sand core. Below the still water level the dike was protected with a concrete block revetment and above the water level there was grass on the clay. The tests were carried out with large waves: $H_{s}=1.6 \mathrm{~m}$. A formula to quantify the erosion of the clay layer as a function of time is derived by combining present and previous experimental results. A formula to quantify the erosion rate of the sand core is derived by combining the present experimental results with existing dune erosion models. The derived formulas make it possible to calculate the probability of failure of the typical Dutch coastal dike with wave attack. This is an important step in the understanding of dike safety.
\end{abstract}

Keywords: residual strength; erosion; wave attack; levee; probability of failure; dike breach

\section{Introduction}

A large part of The Netherlands is protected against flooding by dikes. Both high water levels at rivers and extreme water levels in combination with high waves along the coast, the estuaries and large lakes impose a significant threat. Past flood disasters prove the necessity of proper water defences. Dutch law requires periodic safety assessments of dikes, thereby reflecting the importance of these dikes for the safety of The Netherlands.

An extensive research program has been launched by the Ministry of Infrastructure and Environment (dept. Rijkswaterstaat) to further improve the method to assess the safety of dikes. This research program is carried out by Deltares in cooperation with many research partners and is called 'Strength and loading of flood defenses' (Hamer 2011). One of the research projects in this program deals with the resilience of dikes. It looks into the consequences of damage to a dike, and whether it will lead to a dike breach or not. The residual strength is the amount of the resilience of dikes.

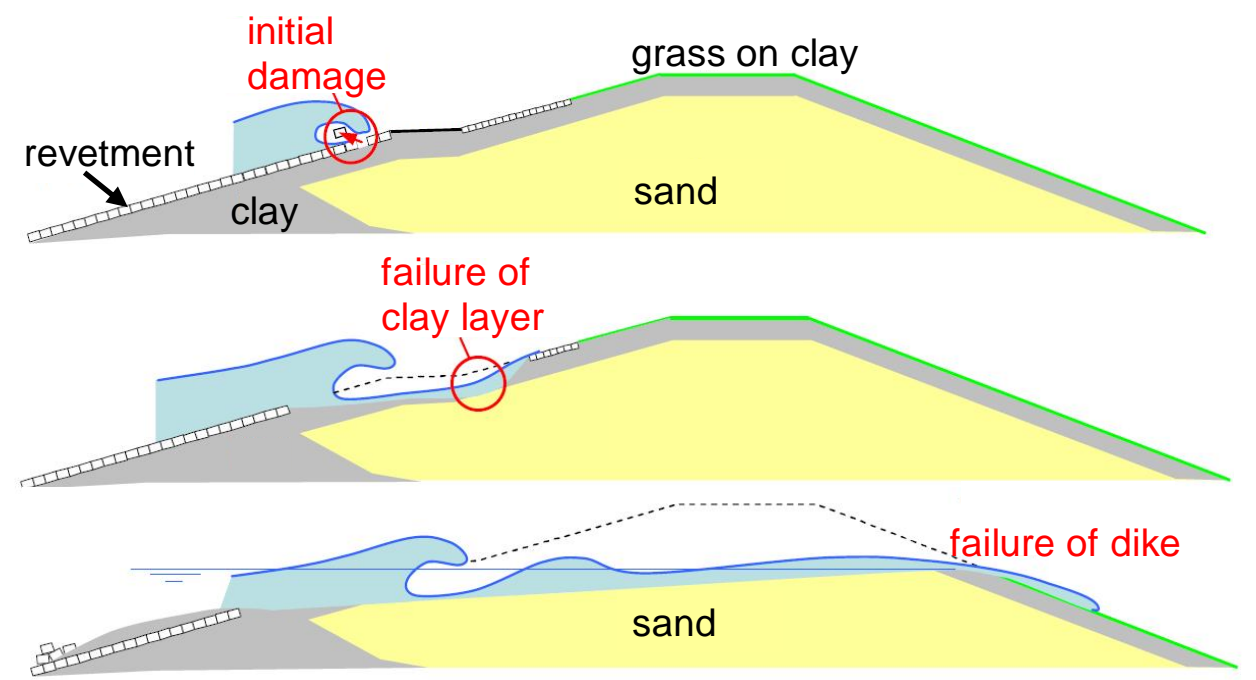

Figure 1, Cross-section of typical Dutch dike and failure process due to wave attack

The residual strength of a dike is defined as the amount of time from the moment of initial damage until the moment the dike breach occurs. When the dike breaches, an increasing flow of water enters the polder, because the crest of the dike is lower than the water level. If the residual strength is

\footnotetext{
${ }^{1}$ Deltares, P.O. Box 177, 2600 MH Delft, the Netherlands

${ }^{2}$ Ministry of Infrastructure and Environment, Rijkswaterstaat Centre for Water Management, P.O. Box 17, 8200 AA,

Lelystad, the Netherlands
} 
larger than the duration of the storm, the initial damage will not lead to inundation. A preliminary desk study into this subject was published at the ICCE 2004 (Coevelt et al 2004).

The present paper focuses on the residual strength of a typical Dutch dike with a core of sand, covered with a layer of clay and grass, and with a block revetment up to the design water level, see Figure 1. The block revetment in the test is designed to provide insufficient protection, and would be damaged due to heavy wave attack in an extreme storm. Following this damage an erosion process of the clay layer and the sand core will start, until the dike breaches. The moment of dike breach is defined as the moment when the erosion has decreased the crest height so much that the highest part of the eroded dike is below the water level.

The present paper gives the results of the analysis of a number of large-scale model tests in the Delta Flume of Deltares (Wolters et al 2011 and 2007, Wouters 1993 and Burger 1985) and dune erosion calculations with the numerical model Durosta (Steetzel 1993).

\section{Process of initial damage and erosion}

If a block revetment is not sufficiently stable, it will probably get damaged during heavy wave attack in a storm. The initial damage can either be the washing out of single block from the revetment, or a number of blocks at the same time (see Figure 2). The damage of block revetments has been investigated several times in the large-scale model facility of Deltares: the Delta Flume (e.g Klein Breteler et al 2006). The flume is $230 \mathrm{~m}$ long, $7 \mathrm{~m}$ deep and $5 \mathrm{~m}$ wide and can generate waves with significant wave height up to $\mathrm{H}_{\mathrm{s}}=1.7 \mathrm{~m}$ and is equipped with active reflection compensation. The large dimensions of the flume make it possible to test the stability of block revetments at nearprototype scale.

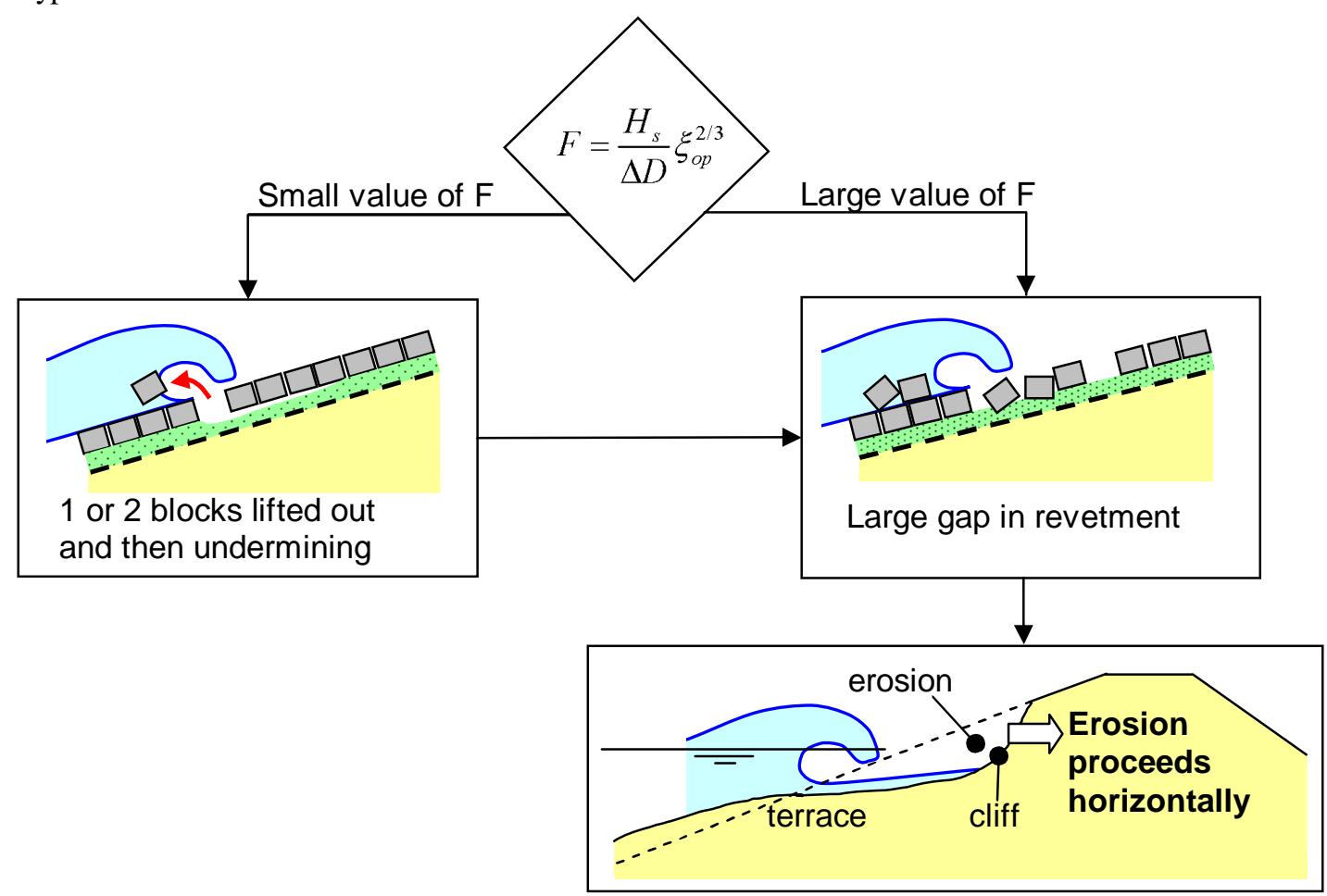

Figure 2, Process of revetment failure and subsequent erosion

From the tests it was concluded that the initial gap size of the revetment is proportional to the ratio of the hydraulic load and the weight of the revetment. This ratio is characterized by the stability parameter F: 


$$
F=\frac{H_{s}}{\Delta D} \xi_{o p}^{2 / 3}
$$

With:

$\mathrm{F} \quad=$ stability parameter of the block revetment (-)

$\mathrm{H}_{\mathrm{s}} \quad$ = significant wave height at the toe of the dike (m)

$\Delta \quad=\left(\rho_{\mathrm{s}}-\rho\right) / \rho=$ relative density of the blocks $(-)$

$\rho_{\mathrm{s}} \quad=$ density of the concrete of the blocks $\left(\mathrm{kg} / \mathrm{m}^{3}\right)$

$\rho \quad=$ density of the water $\left(\mathrm{kg} / \mathrm{m}^{3}\right)$

$\mathrm{D}=$ cover layer thickness $(\mathrm{m})$

$\xi_{\text {op }}=\tan \alpha /{\sqrt{\mathrm{s}_{\mathrm{op}}}}=$ breaker parameter $(-)$

$\mathrm{s}_{\mathrm{op}} \quad=\mathrm{H}_{\mathrm{s}} / \mathrm{L}_{\mathrm{op}}=$ wave steepness based on the theoretical deepwater wave length (-)

$\mathrm{L}_{\mathrm{op}} \quad=\mathrm{gT}_{\mathrm{p}}^{2} /(2 \pi)=$ theoretical deepwater wave length based on the peak period $(\mathrm{m})$

$\mathrm{T}_{\mathrm{p}} \quad=$ wave period at the peak of the spectrum (s)

$\mathrm{g} \quad=$ acceleration of gravity $\left(\mathrm{m} / \mathrm{s}^{2}\right)$

The test results have shown that a small gap in the revetment will occur if the value of $F$ at the start of damage is rather small (in a range of 4 to 6); a larger gap will occur for high values of F. This can be explained from the interaction forces between the blocks. If these blocks have hardly any interaction, a single block can be lifted out of the revetment with a force smaller than say twice the own weight of the block. In that case the revetment will get damaged at a relatively small value of $\mathrm{F}$, and probably only a single block will be lifted out of the revetment. This will lead to a small initial gap in the revetment. On the other hand, if there is a large interaction between the blocks, the revetment will rather form an S-profile during heavy wave attack. Individual blocks will not be washed out. At a relatively large load (high value of F), a group of blocks will collapse (the revetment bursts open) leading to a large initial gap.

If only a small gap is formed, the next step in the process will be the undermining of the remaining revetment around the gap. The granular filter under the revetment will wash out through the gap, until the undermined revetment collapses under the forces of the breaking waves. That will lead to a large gap, which will quickly grow. After some time, the entire revetment is washed away and the clay erosion starts.

The erosion of the clay starts well below the still water level, where the waves impact on the slope. From there the erosion will grow to the waterline. In this phase a shallow terrace will be formed, fronting a steep cliff, as illustrated in Figure 2 (bottom panel). This erosion will progress mostly horizontally into the dike, while the cliff moves backwards and the terrace slowly becomes lower. Such an erosion profile conforms to the natural cliff coasts shown here in Figure 3 for a coast in Poland.

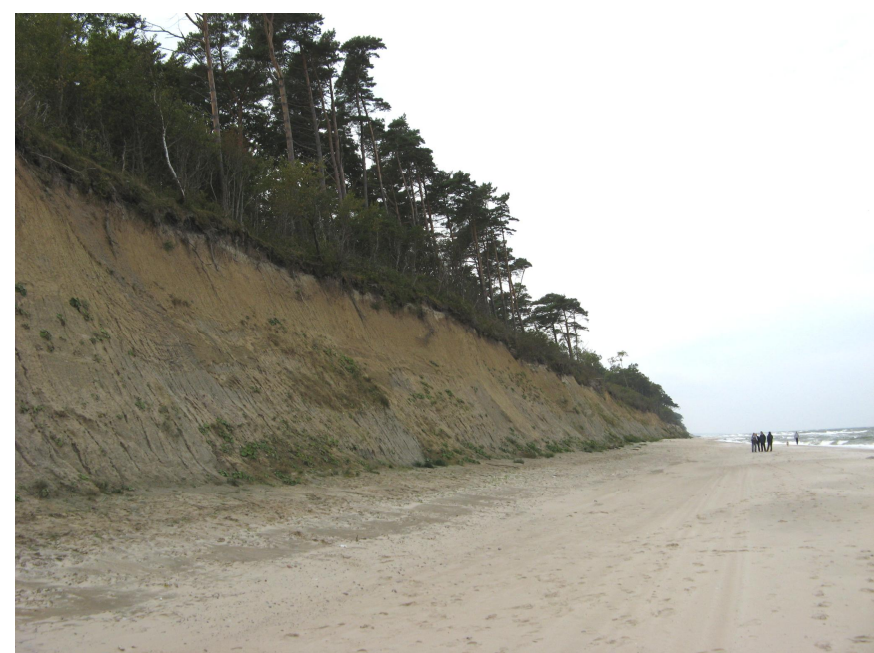

Figure 3, Example of eroding coast with steep cliff (Poland) 


\section{Clay erosion; theory}

The influence of the weather, such as dry/wet and cold/warm seasons and related physical, biological and chemical processes in the clay liner leads to a so-called macro soil structure, here refered to as 'structured clay'. The processes result in cracks and fissures in the clay, dissintegrating the liner into large and small lumps of clay (several $\mathrm{mm}$ up to a few decimeter) in a specific vertical profile with decreasing intensity with depth, near vanishing below about $1.2-1.5 \mathrm{~m}$ in The Netherlands.

At the start of the erosion it is primarily the wave impacts that are able to wash out the clay lumps from the clay layer. The high pressure on the surface due to the wave impact leads to compression of the air in the water in the larger pores in the clay liner. After the wave impact the compressed water air mixture results in uplift pressures on the clay lumps untill the pore pressure is dissipated.

Numerical calculations (Finit Element Method) with a suitable consolidation model (Kruse 1993 and 1998) can simulate the internal pressures relevant this process reasonably well, as shown by Figure 4. The pressure measurements were performed in the clay by installing a pore pressure cell in cracks at a depth of 0.1 and $0.3 \mathrm{~m}$ below the surface. The wave impact on the surface (green line) was measured a few metres from the pressure cell in the clay. It will be understood that the heterogeneity of the surface of the clay during erosion and of clay structure is considerable.

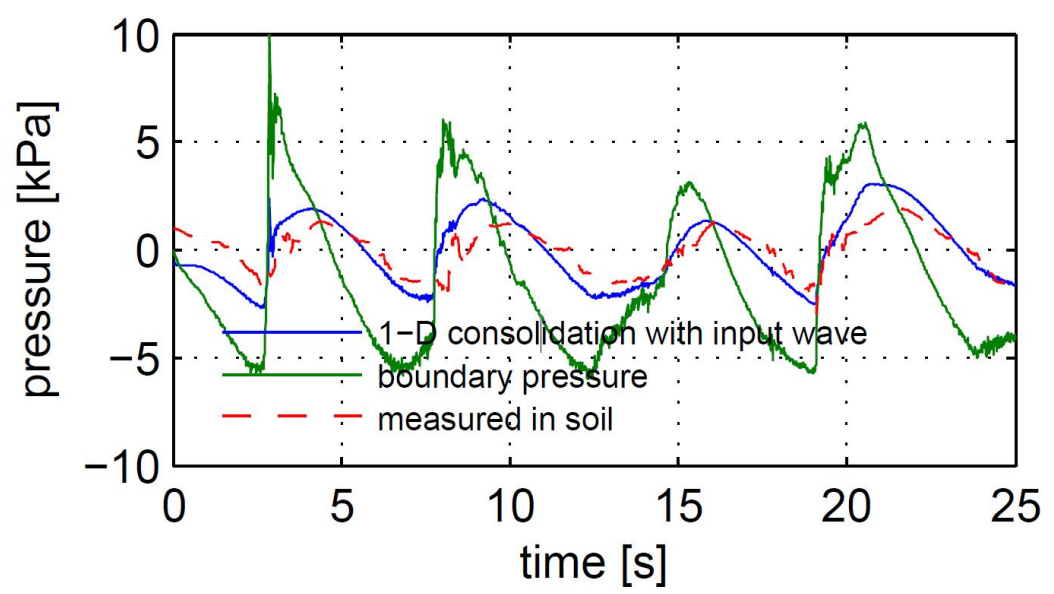

Figure 4, Measured and calculated pressure in the clay at a depth of $30 \mathrm{~cm}$ and at the surface

As the clay liner erodes, an erosion profile is formed with a shallow terrace and a steep cliff. The profile has been given schematically in Figure 5. The depth of the terrace is such that most of the time it is covered by a water layer, including the wave run-downs. The layer of water forms a cushion for the wave impacts, which results in a much lower wave impact pressure on the clay than without this water layer. All in all, the erosion of the terrace is fairly slow, both because of this cushion effects and because of the very gentle slope of the terrace.

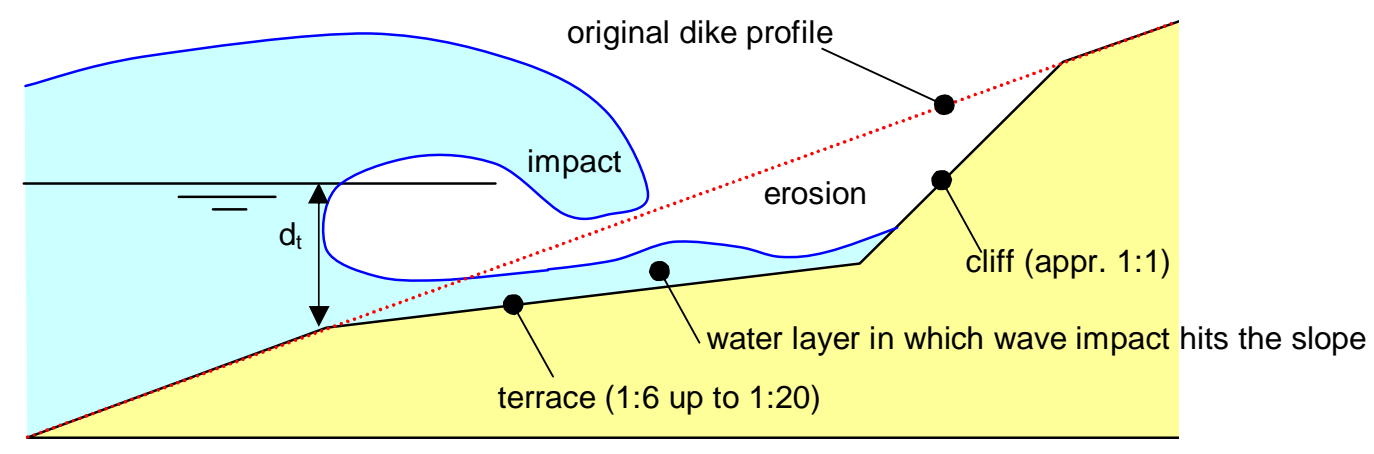

Figure 5, Schematised erosion profile 
The terrace has an important influence on the hydraulic load. It is the region where the waves are breaking and lose a lot of their energy. This energy loss has been calculated with the numerical model ComFLOW. ComFLOW is a generic 3D Volume-of-Fluid (VOF) model to solve the incompressible Navier-Stokes equations including free surface, or to solve the Navier-Stokes equations for two-phase flow problems (for example with incompressible water and compressible air). The detailed description of the free surface in the one-phase model, or the water-air interface in the two-phase model, allows for accurate simulation of breaking waves. ComFLOW can be applied in 2DV ('flume') and in 3D ('basin') mode. In the field of coastal engineering, ComFLOW has been validated for, amongst others, wave impacts on a dike (Wenneker et al, 2010) and for wave interaction with porous media (Wellens et al 2010, Wellens et al 2012).

One of the results of the ComFLOW calculations is given in Figure 6. It shows the wave height as a function of the location on the terrace. Note that about $1 / 3$ of the wave height is lost over only a distance of $5 \mathrm{~m}$. Near the cliff the wave height seems to increase again, but that is actually caused by the wave run up.

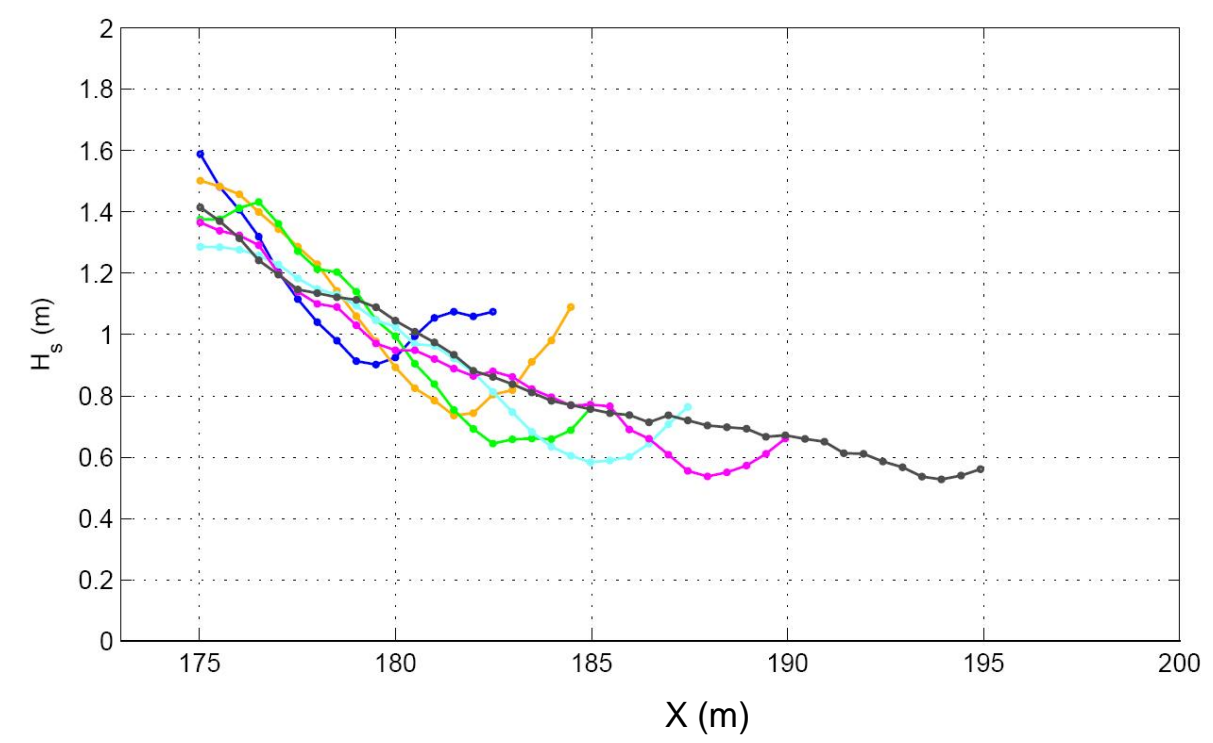

Figure 6, Results of computations with the numerical model ComFLOW (each line corresponds with a certain erosion profile as measured during the tests, see Figure 12)

Formulas to predict the erosion of clay due to breaking waves are scarce in literature. A useful starting point for the derivation of an erosion formula is given by Verhey and Giri (2010), who proposed the following formula based on Partheniades (1965) and Osman and Thorne (1988):

$$
E_{\perp}=C k_{c} r_{0}^{2} \rho g \xi_{o p} H_{s} t
$$

In which $\mathrm{E}_{\perp}=$ erosion depth (perpendicular to the slope surface) $(\mathrm{m}), \mathrm{H}_{\mathrm{s}}=$ significant wave height $(\mathrm{m}), \xi_{\mathrm{op}}=\tan \alpha / \sqrt{ }\left(\mathrm{H}_{\mathrm{s}} /\left(\mathrm{gT}_{\mathrm{p}}{ }^{2} /(2 \pi)\right)\right)=$ breaker parameter $(-), \mathrm{T}_{\mathrm{p}}=$ wave period at the peak of the spectrum (s), $\mathrm{C}=$ erosion coëfficiënt $(-) ; \mathrm{r}_{0}=$ turbulence intensity parameter $(-) ; \rho=$ water density $\left(\mathrm{kg} / \mathrm{m}^{3}\right)$ and $\mathrm{k}_{\mathrm{c}}=$ erosion coëfficiënt $(-)$.

Assuming the erosion profile as given in Figure 5 there is a straightforward relation between the erosion volume $\mathrm{V}_{\mathrm{e}}$ and the erosion depth:

$$
E_{\perp} \triangleq \sqrt{V_{e} \tan \alpha}
$$

Combining the above formulas gives the basis for a formula for the erosion of clay due to wave attack:

$$
V_{e} \triangleq \frac{H_{s}^{2} \tan (\alpha)}{s_{o p}} \cdot f\left(B_{\text {terrace }}\right)
$$

In this formula a term has been included to account for the influence of the width of the terrace: $f\left(B_{\text {terrace }}\right)$. It is expected that when the width of the terrace increases, the erosion rate will decrease. 
Large-scale experiments, as described in the next section, are used to verify this preliminarily formula and to further develop it.

\section{Clay erosion; large-scale model tests}

Unique experiments have been carried out in the Delta Flume of Deltares in 2010. A full-size dike was built in the flume with the following characteristics (see Figure 7):

- $\quad 3.6 \mathrm{~m}$ wide berm at the still water level

- Slope of 1:3.5 under the berm, and 1:3 above

- Crest at $8.5 \mathrm{~m}$ above the flume bottom

- Inner slope of 1:2.5

- $\quad$ Core of sand $\left(\mathrm{D}_{50}=0.2 \mathrm{~mm}\right)$

- $80 \mathrm{~cm}$ thick clay layer on both the outer slope and inner slope

- Up to the berm a block revetment of Basalton

- On the berm a $2.1 \mathrm{~m}$ wide asphalt maintenance road on phosphorus slags.

- Upper slope, crest and inner slope: grass

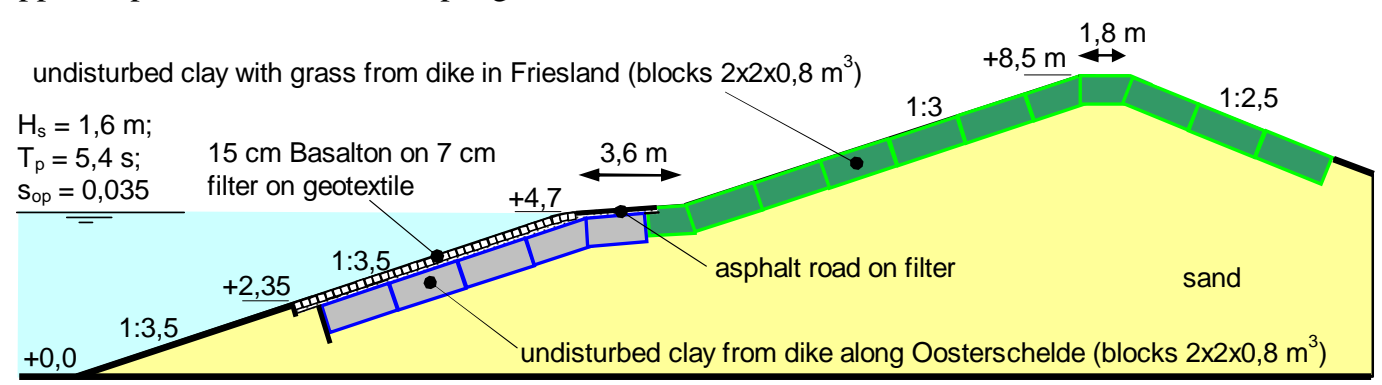

Figure 7, Cross-section of test set-up in Delta Flume

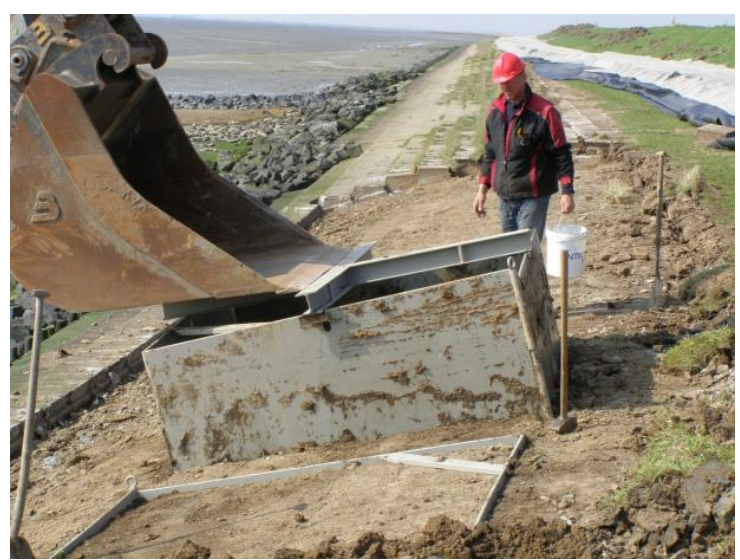

Figure 8, Pushing the steel box without bottom into the clay with hydraulic crane

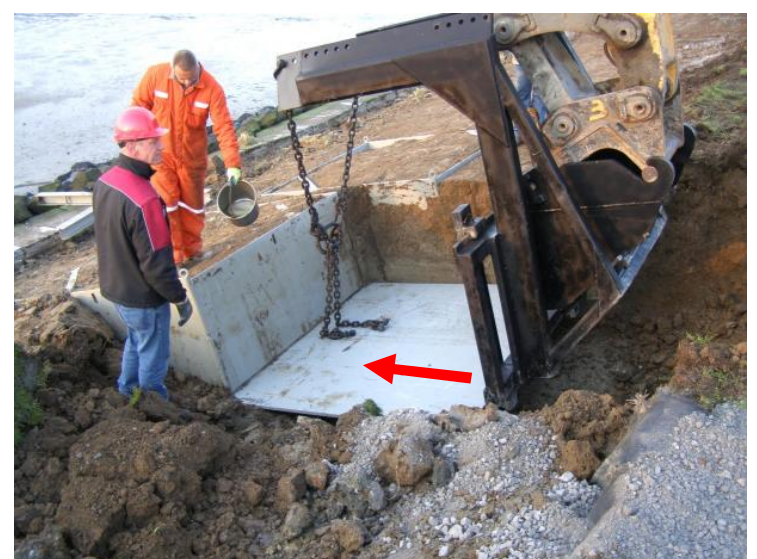

Figure 9, Pushing the steel plate underneath the clay block 
The clay was placed in the flume without disturbing its characteristic structuring, which typically develops over the years. Steel boxes of $2 \times 2 \mathrm{~m}^{2}$ without bottom were pushed in the clay on a dike to harvest the clay (Figure 8). After pushing the box into the clay, the clay around it was removed and a steel plate could be pushed underneath the clay block (Figure 9). The clay was then fully secure in the steel box, and could be transported and installed in the Delta Flume. In this way 32 clay blocks of 3.2 $\mathrm{m}^{3}$ each were used to build the test setup. During installation the clay blocks were pushed against each other with hydraulic jacks, which led to hardly visible joints between the blocks.

Ten porewater pressure cells were installed in the clay, making sure macro pore space was measured, and 15 on top of the slope (adjacent to the clay on non eroding part of slope) in the region where waves impact on the slope. These were used to verify the numerical calculations.

At first, tests with stepwise increased wave height were carried out, to measure the wave height at which damage of the block revetment takes place: $H_{s}=1.6 \mathrm{~m}, \mathrm{~T}_{\mathrm{p}}=5.4 \mathrm{~s}$ (wave steepness: $\mathrm{s}_{\mathrm{op}}=$ 0.035). The wave conditions were then kept constant for many hours, while the tests were interrupted frequently to measure the erosion profile.

Further details regarding these tests are given by Wolters et al (2011).
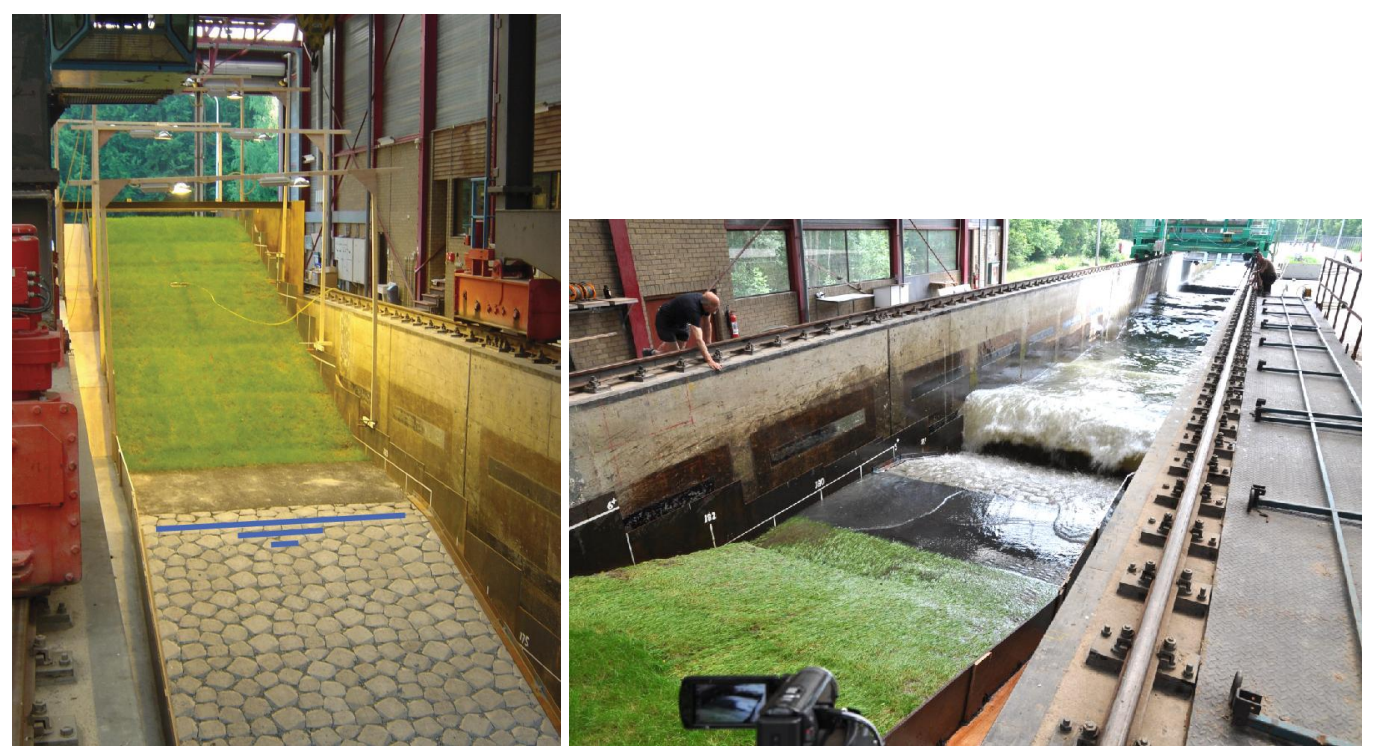

Figure 10, Model set-up in the Delta Flume
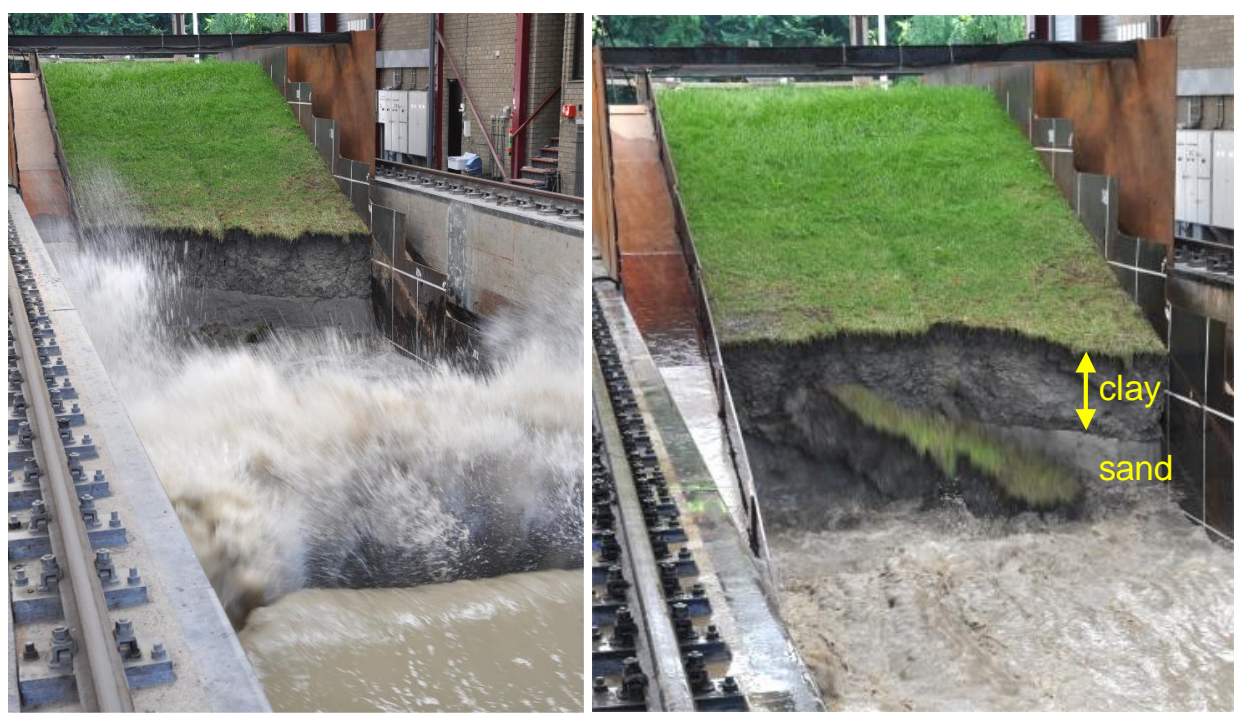

Figure 11, Erosion process: undermining of the clay layer 
At first only the clay was eroding, but once the waves had cut through the clay layer, the erosion velocity increased substantially. In that phase the sand was eroding leading to undermining of the clay layer, after which lumps of clay fell down. This can also be seen in Figure 11.

At several moments the water level in the flume was lowered to inspect the erosion. The erosion profiles (average over the width of the flume) are given in Figure 12.

Without intervention, the eroded clay would gradually form a sedimentation berm in front of the dike. In reality such sedimentation could wash away along the dike due to (tidal) currents along the dike, or oblique wave attack. By regularly removing such sedimentation berms, a realistic (if the berm washes away) or conservative (if it doesn't wash away) result was obtained.

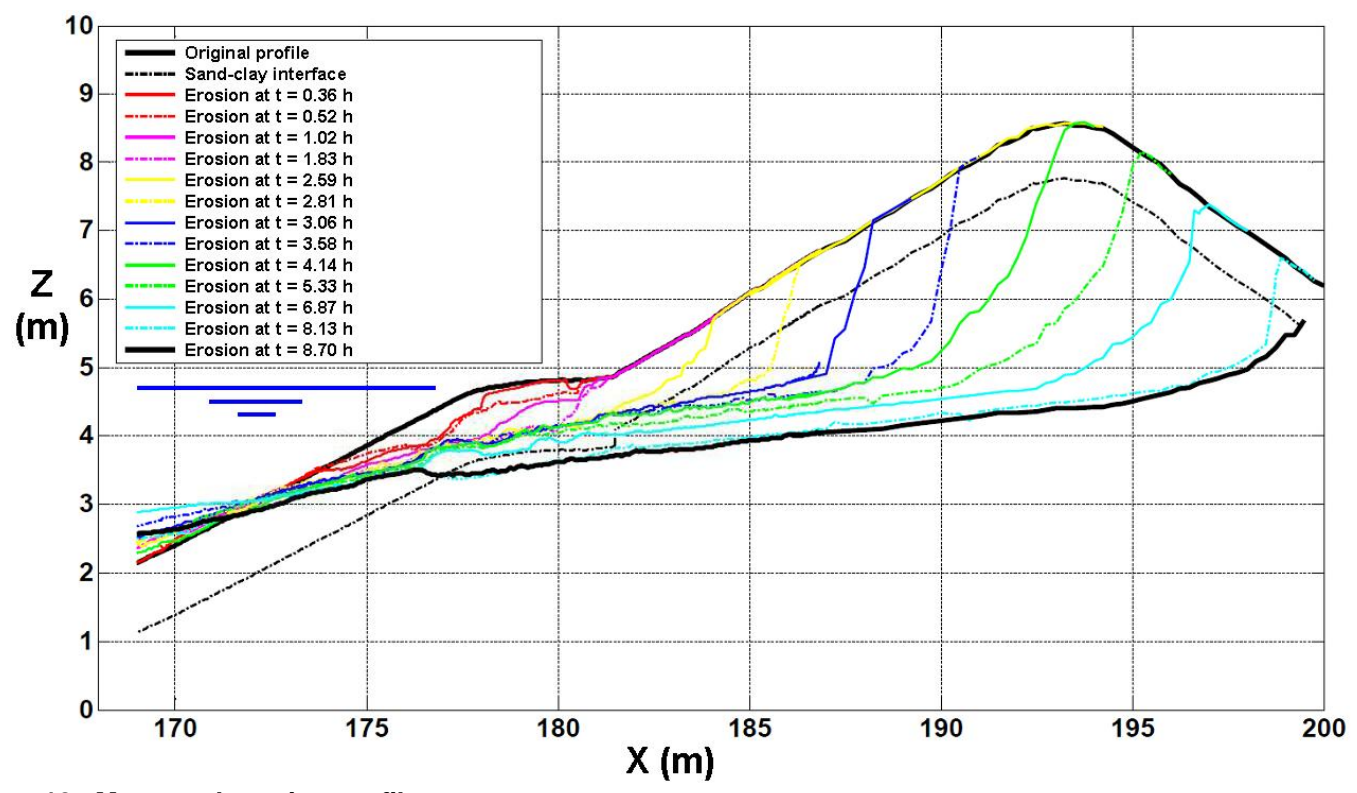

Figure 12, Measured erosion profiles

The results of these tests regarding the erosion of the clay have been analysed together with other erosion tests from the past (Wolters 2007, Wouters 1993 and Burger 1985). All test results are gathered in Figure 13.

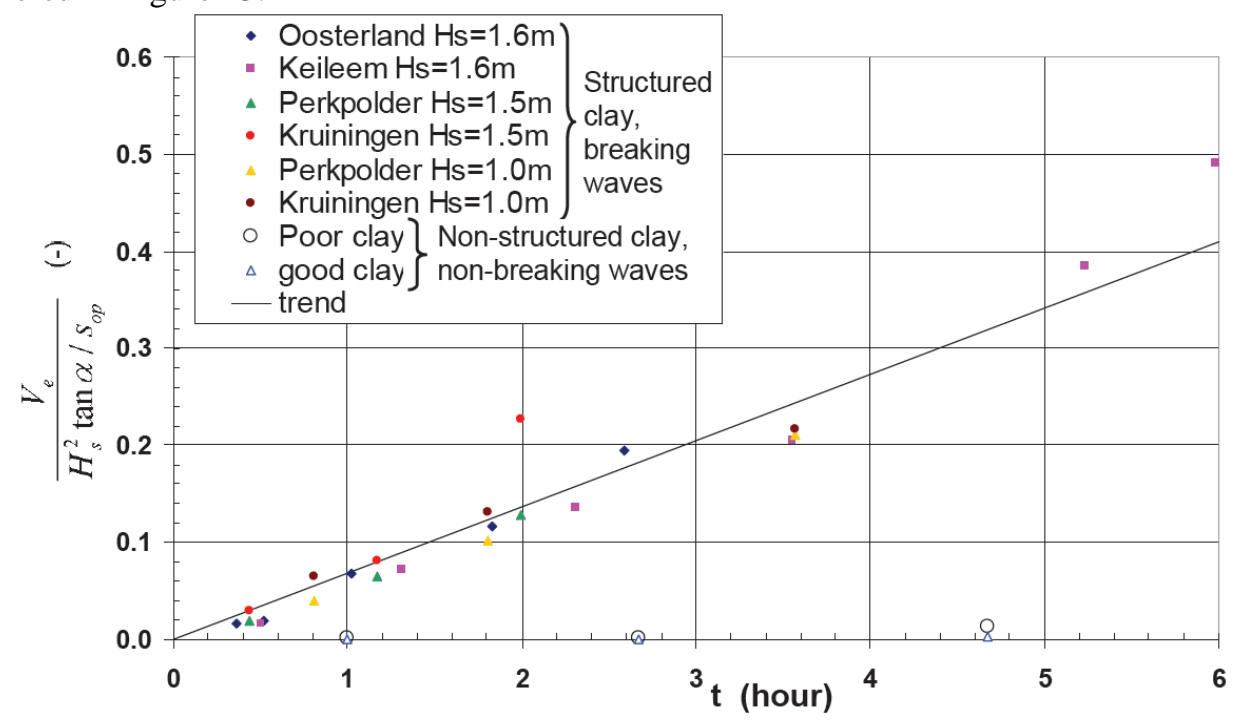

Figure 13, Measured erosion volume of clay as a function of duration of wave attack (Oosterland is present tests, Keileem is from Wolters 2007, Perkpolder and Kruiningen is from Wouters 1993 and non-structured clay is from Burger 1985) 
On the vertical axis the dimensionless erosion volume $\mathrm{V}_{\mathrm{e}} /\left(\mathrm{H}_{\mathrm{s}} \mathrm{tan} \alpha / \mathrm{s}_{\mathrm{op}}\right)$ is given, which results from the theoretical analysis (formula 4). The total duration of wave attack is given on the horizontal axis. It is remarkable to see that -even when relating to different test conditions- most results for structured clay can be well described by a single linear relation. The standard deviation of the results is relatively small for this kind of measurements. There was actually quite a difference between the clay quality of Oosterland (present tests), Keileem (Wolters 2007), Kruiningen and Perkpolder (Wouters 1993), but these clay-quality differences do not seem to show up in the results. The clay that was used in these tests have something very important in common: all clay was structured. The latter means that a continuous process over years of getting wet and dry, cold and warm, has formed a network of cracks in the clay. These cracks sometimes close, but because of chemical and biological influences they do not disappear, and still form a weak point for erosion processes. From the test results it seems that the soil structure is more important than other characteristics like the Atterberg Limits and the grain size distribution, in agreement with i.e. Levebre and Rohan (1986). This is further confirmed by the tests which are carried out with unstructured clay (open circle and triangle in the figure). The erosion rate for these test results is much smaller than for the structured clay, and does not fit the linear relationship in Figure 13.

The following formula is proposed for structured clay, which is very common on dike slope sections above the average still water level:

$$
V_{e}=0,07 \frac{H_{s}^{2} \tan \alpha}{s_{o p}} t
$$

for $1<\mathrm{H}_{\mathrm{s}}<2 \mathrm{~m}, \mathrm{~s}_{\mathrm{op}}>0,02$, layer thickness of clay $<3 \mathrm{~m}$ and clay from Dutch dikes above average high water (with soil structuring) with normal amount of entrapped sand, with $\mathrm{V}_{\mathrm{e}}=$ erosion volume per metre dike $\left(\mathrm{m}^{3} / \mathrm{m}\right), \mathrm{H}_{\mathrm{s}}=$ significant wave height at the toe of the dike $(\mathrm{m}), \mathrm{s}_{\mathrm{op}}=$ $\mathrm{H}_{\mathrm{s}} /\left(\mathrm{gT}_{\mathrm{p}}^{2} /(2 \pi)\right)=$ wave steepness based on the significant wave height and peak period (-), $\mathrm{T}_{\mathrm{p}}=$ wave period at the peak of the spectrum (s), $\alpha=$ slope angle $\left({ }^{\circ}\right), t=$ duration of the wave attack (hour)

The theoretical analysis also suggests that the erosion rate probably decreases if the width of the terrace (volume of the erosion) increases. The linear relation between erosion rate and time suggests that such terrace width effects are relatively small for conditions comparable with the present (and previous) test conditions (clay layer not thicker than $3 \mathrm{~m}$ ).

\section{Erosion of the sand core; theory}

Once the waves have cut through the clay layer, the erosion is dominated by the erosion of the sand. From that moment on the clay has only a minor influence on the erosion rate. This opens the possibility to quantify the erosion rate with the tools that have been developed for dune erosion.

Quantifying the dune erosion as a function of time is relatively complicated and requires a numerical model. Examples of such model are Durosta (Steetzel 1993) and Xbeach (Roelvink et al 2009 and Van Thiel de Vries 2009). Compared to a dune, the dike has a very steep front and rather deep water in front of it. That makes that not all numerical models are equally suitable. It turned out that Durosta provides the best results.

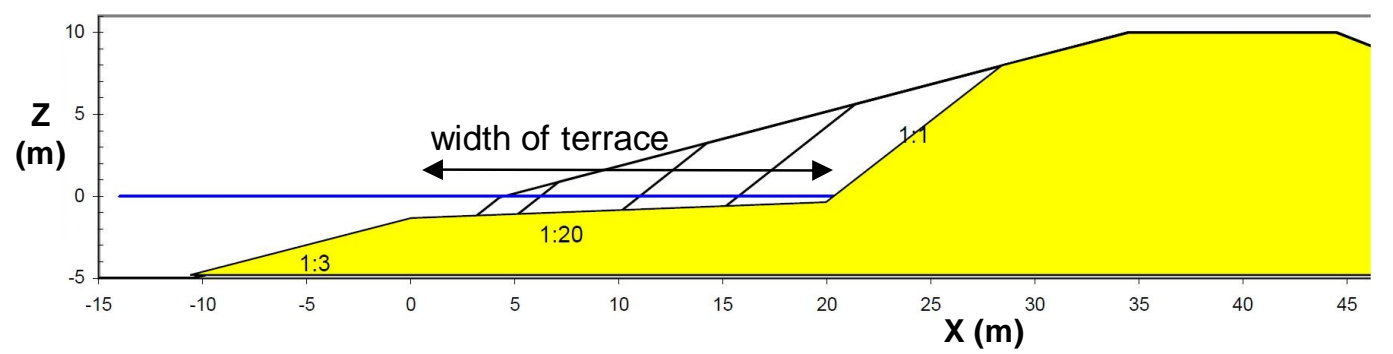

Figure 14, Example of profiles used for dune erosion calculations 
In the present research many calculations with Durosta have been performed to derive a simple set of formulas to quantify the erosion volume as a function of time. Such simple formulas are necessary because the objective is to use the results of the research for probabilistic calculations of the probability of dike failure. Straightforward formulas are much easier to use in probabilistic calculations than numerical models.

Since the erosion rate decreases with increasing erosion volume (width of the terrace, see Figure 5) the calculations have been set up such that this decreasing erosion rate can be quantified. The erosion rate is defined as $\partial \mathrm{V}_{\mathrm{e}} / \partial \mathrm{t}$.

Many calculations of the dune erosion for 1 hour of wave attack were performed with a variety of wave conditions, width of the terrace (see Figure 14) and slope angle, to quantify the erosion rate. The significant wave height was varied between 1 and $2.5 \mathrm{~m}$, the wave period between 4 and $7 \mathrm{~s}$, the slope angles of the dike used in the calculations were 1:2, 1:3 and 1:4, and the terraced width was varied between $3 \mathrm{~m}$ and $40 \mathrm{~m}$. All calculations were carried out with a grain size of the sand of $\mathrm{D}_{50}=0.20$ $\mathrm{mm}$.

An example of the results is given in Figure 15.

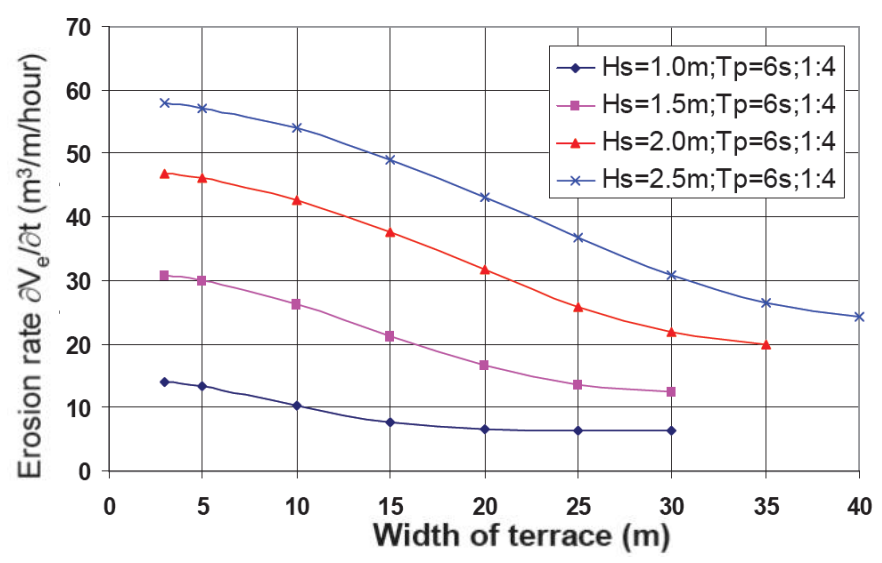

Figure 15, Example of results of dune erosion calculations (volume of erosion during one hour, starting with the profile with the given width of the terrace)

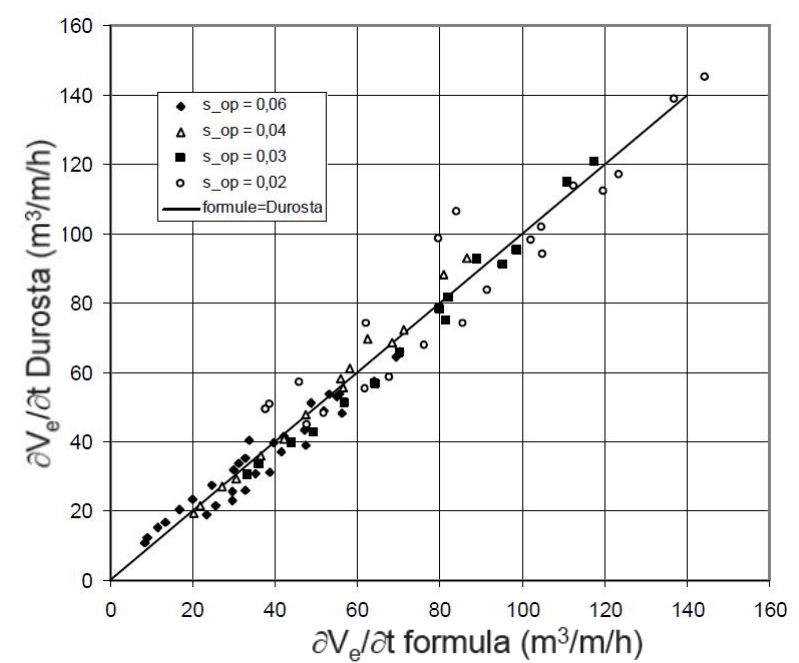

Figure 16, Erosion rate according to numerical model as a function of the calculated erosion rate with the preliminary formula

The analysis of the results of all calculations has led to the following preliminarily formula that can be compared with the results of large-scale model tests: 


$$
\frac{\partial V_{e}}{\partial t}=\frac{H_{s}^{2}}{T_{p}}\left(\frac{0,26}{s_{o p}^{1,3}}+(\tan \alpha)^{0,8} \cdot\left(235-2600 \cdot s_{o p}\right) \cdot \exp \left(-0,0091 \cdot\left(\frac{B_{t}}{H_{s}}\right)^{2}\right)\right)
$$

In which $B_{t}=$ width of the terrace $(m)$.

Figure 16 gives an impression of the quality of the formula.

\section{Erosion of the sand core; large-scale model tests}

The preliminary formula derived from the dune erosion calculations was compared with the largescale model tests described earlier in this paper, using the measured erosion profiles in Figure 12.

The red line in Figure 17 clearly shows that the erosion according to the preliminary formula overestimates the measured erosion. This could be because Durosta is not developed for a dike profile, but it can also be because of the influence of the clay layer, which might reduce the erosion rate. Therefore the erosion formula has been adapted to match the measurements:

$$
\frac{\partial V}{\partial t}=\frac{H_{s}^{2}}{T_{p}}\left(\frac{0,15}{s_{o p}^{1,3}}+(\tan \alpha)^{0,8} \cdot\left(135-1500 \cdot s_{o p}\right) \cdot \exp \left(-0,0091 \cdot\left(\frac{B_{t}}{H_{s}}\right)^{2}\right)\right)
$$

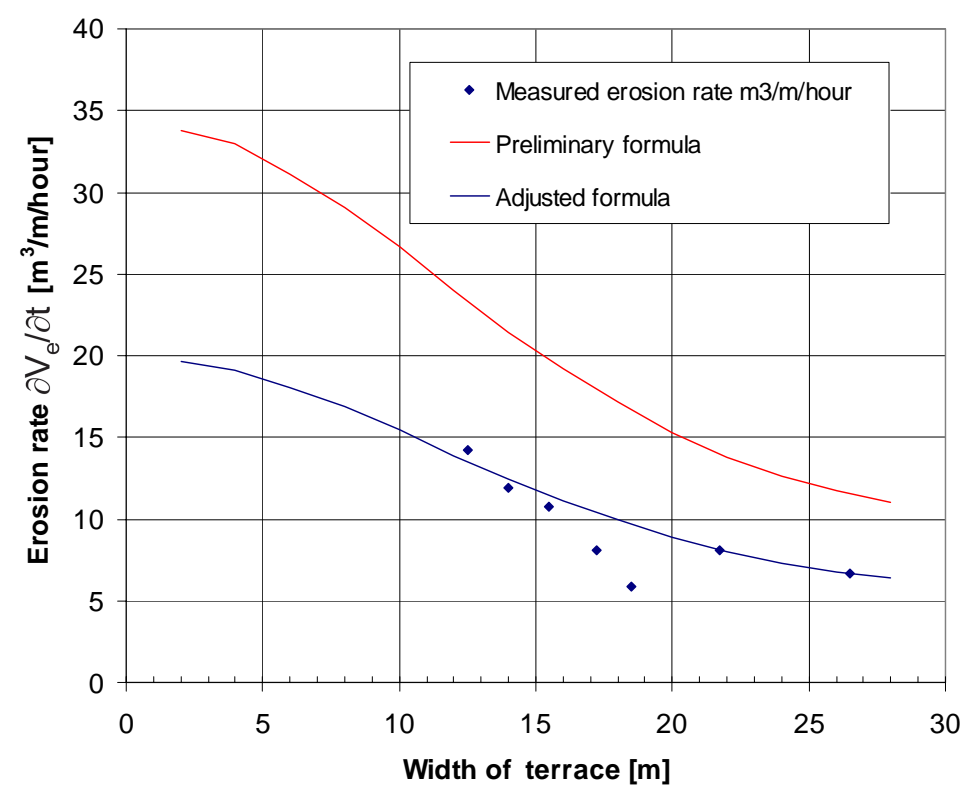

Figure 17, Erosion rate as a function of the width of the terrace

This formula can be used to calculate the erosion of a dike core during a storm, if the grain size is $\mathrm{D}_{50}=0.20 \mathrm{~mm}$ (a larger grain size gives less erosion). Usually this will be carried out with time steps in which the wave conditions are constant. This formula was derived in such a way that the width of the erosion terrace at the beginning of the time step should be used.

\section{Erosion profile}

From the measurements we have concluded that the erosion profile develops in three stages:

1. If the erosion volume is small, the erosion terrace is relatively steep, steeper than $1: 8$. The foot of the cliff is below the waterline at a level of approximately $\mathrm{SWL}-\mathrm{H}_{\mathrm{S}} / 4$.

2. In the second stage the foot of the cliff rises to the waterline, while the terrace has a slope of approximately 1:8

3. In the final stage the foot of the cliff is at the waterline, while the terrace has a very gentle slope, less steep than 1:8. 
These stages are shown in figure 18. Throughout all stages the cliff remains very steep, with the steepness of approximately 1:1.

The depth of the erosion terrace $d_{t}$ gradually increases as a function of time, starting well below the still water level. Because it seems obvious that there is a relation between the depth of the erosion terrace and the erosion volume, the measurements have been plotted against the dimensionless erosion volume $\mathrm{V}_{\mathrm{e}} / \mathrm{H}_{\mathrm{s}}^{2}$. Unfortunately there was no clear relation between $\mathrm{V}_{\mathrm{e}} / \mathrm{H}_{\mathrm{s}}{ }^{2}$ and the dimensionless depth $\mathrm{d}_{\mathrm{t}} / \mathrm{H}_{\mathrm{s}}$. In Figure 19 the relation between $\mathrm{V}_{\mathrm{e}} / \mathrm{H}_{\mathrm{s}}{ }^{2}$ and $\mathrm{d}_{\mathrm{t}}$ is given, from which it is concluded that the following empirical formula gives a reasonable result:

$$
d_{t}=0,4 \frac{V_{e}^{0,25}}{\sqrt{H_{s}}}+0,7 \text { for } \mathrm{H}_{\mathrm{s}}>0.7 \mathrm{~m}
$$

Further research is necessary to find a proper dimensionless formula.

1. Start of erosion with relatively steep terrace:

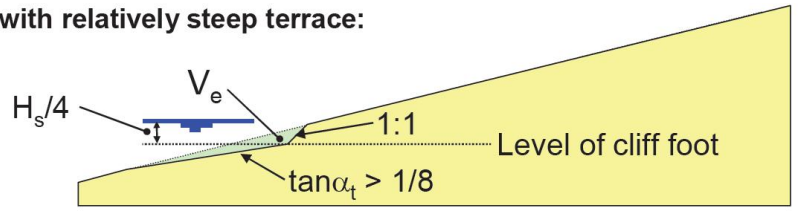

2. Intermediate stage: foot of cliff rises to waterline:

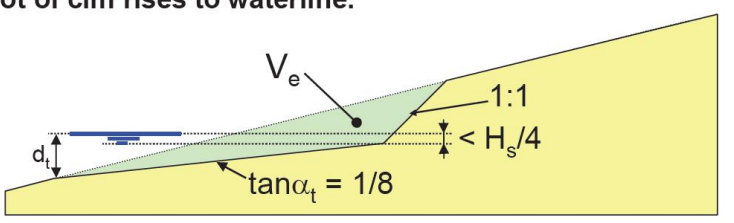

3. Final stage: very gentle terrace:

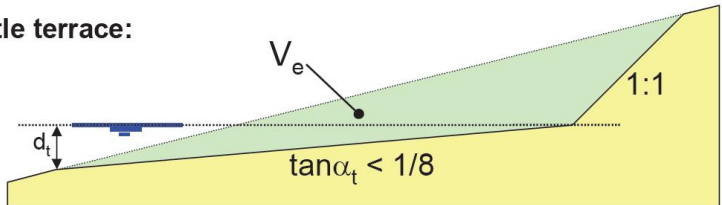

Figure 18, Development of the erosion profile

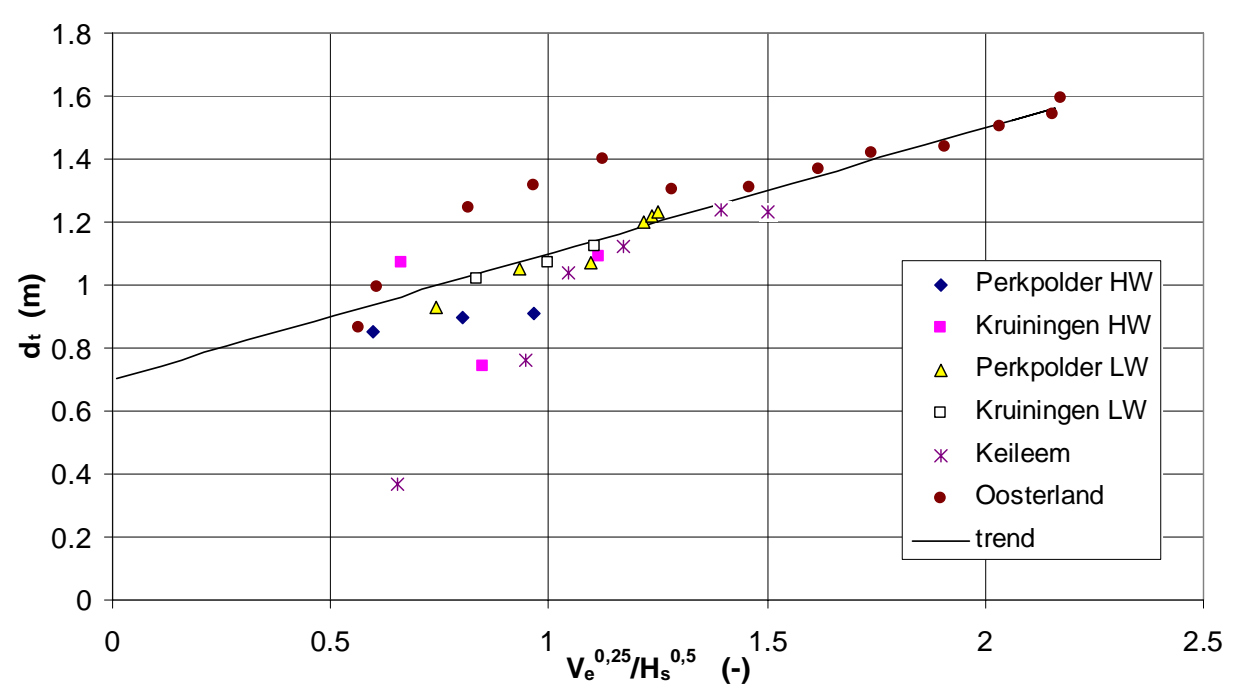

Figure 19, Measured depth of the terrace as a function of the dimensionless erosion volume

\section{Conclusions}

By bringing together the results of the large scale experiments, numerical calculations and theoretical considerations, it was possible to derive a set of formulas with which the erosion of the clay 
layer and the sand core of a dike during wave attack can be calculated. These formulas are relatively accurate in the prediction of the erosion of the dike. Yet, the formulas are kept sufficiently simple to be able to use them in probabilistic calculations. It enables us to calculate the probability of a dike breach, once damage occurs at the block revetment during wave attack.

This is an important step in the understanding of dike safety.

The research has led to the following conclusions regarding the investigated aspects of erosion:

- Erosion of the clay layer:

- There is a linear relation between erosion volume and duration of wave attack for structured clay (usually found up to approximately $1 \mathrm{~m}$ below the clay surface)

- The erosion rate of unstructured clay is much smaller than structured clay

- Within limits there is a negligible influence of the clay quality in terms of classification properties (i.e. grainsize, Atterberg limits) for clay with a soil structure

- Erosion of the sand core:

- The erosion rate of the sand core of the dike is less than for dunes

- There is a large influence of the terrace width

- Erosion profile:

$\circ$ A gentle terrace is formed just below SWL; above the waterline there is a steep cliff (with steepness of approximately 1:1)

- The erosion profile develops in three stages, starting with a rather steep terrace (steeper than 1:8) and with the foot of the cliff below the water level, and it ends with a very gentle terrace (less steep than 1:8) and the foot of the cliff at the water level, see Figure 18.

- The formulas (5), (7) and (8) are derived, which are suitable for probabilistic calculations.

\section{Acknowledgement}

This research was funded by Rijkswaterstaat (part of the Dutch ministry of Infrastructure and Environment) in the framework of SBW (Strength and loading of flood defences).

\section{References}

Burger; Stability of Oosterschelde dikes under wave action (in Dutch); Delft Hydraulics, report M2036, 1985.

Coeveld et al; Residual strength of dike after failure of cover layer; ICCE, Lisbon, 2004

Grondmechanica Delft 1993: PLUTO: Toepassing van het eindige elementeprogramma PLUTO in de geotechniek. Grondmechanica Delft rapport SE-57043

Hamer et al; Strength and loading of flood defences; Deltares publication 2011; SBW@Deltares.nl.

Klein Breteler, M., R. 't Hart and T. Stoutjesdijk; Influence of wave steepness on stability of placed block revetments; Proceedings of 30th ICCE conference, San Diego USA, 2006

Kruse G.A.M.; Build up and erosion of grass sods on dikes. GeoDelft report CO-307282/18 for Rijkswaterstaat DWW, Delft, 74 pp (in Dutch), 1993.

Kruse, G.A.M., J.D. Nieuwenhuis; Impact of weathering on erosion resistance of cohesive soil. Proc. 8th Congress IAEG Congress, Balkema, Rotterdam, pp.4299-4306, 1998.

Kruse G.A.M.; Study for guidelines for clay on dike slopes in the river areas. (in Dutch) Deltares rapport 1202512-000-GEO-0002, 110 pp (in Dutch), 2010.

Lefebre, G., K. Rohan; On the principal factors controlling erosivity of undisturbed clay. In: Proc. Symp. on Cohesive Shores, Natl. Res. Council Canada, pp 170-195, 1986.

Roelvink, D., A. Reiniers, A. van Dongeren, J. van Thiel de Vries, R. McCall, J. Lescinski; Modelling hurricane impact on beaches, dunes and barrier islands. Coastal engineering 2009.

Steetzel, H.J.; Cross shore transport during storm surges, Ph.D. thesis Delft University of Technology 1993 
Van Thiel de Vries, J.S.M.; Dune erosion during storm surges, Ph.D. thesis Delft University of technology 2009

Wellens, Borsboom and Van Gent. 3D simulation of wave interaction with permeable structures. ICCE 2010.

Wellens, P. and M.R.A. van Gent; wave induced setup in permeable structures; ICCE 2012.

Wenneker, Wellens and Gervelas (2010). Volume-of-Fluid model ComFLOW simulations of wave impacts on a dike. ICCE 2010.

Wolters et al; Dike erosion strength after initial damage; Coastal Structures Conference 2011, Yokohama, Japan

Wolters et al; Delta Flume tests to measure the strength of bolder clay of Wieringermeer dike (in Dutch); Deltares, report H4739, 2007.

Wouters, Residual strength of block revetment on clay (in Dutch), Delft Hydraulics, report H195, 1993

Verhey, H. and S. Giri; Reststerkte van een kleidijk met gras (rivierdijken); deel 4 in Reststerkte van dijken na initiële schade; SBW-reststerkte fase 1: inventarisatie, Deltares, report 1200393 / 1202122,2010

Osman, A.O. and Thorne, C.R., Riverbank stability analysis. I: Theory. Journal of Hydraulic Engineering, ASCE, Vol. 114, No. 2, pp. 134-150, 1988.

Partheniades, E., 1965. Erosion and deposition of cohesive soils. Journal of Hydraulic division, 91(1), 105-138. 